\title{
LACK OF SHAME AND DECEPTION IN SPORT
}

\author{
Jovo Radoš \\ University of Belgrade
}

\section{SUMMARY}

The subject of this paper is a brief review of a worldwide decreasing and loosing of moral values and moral norms in any field of human existence and in sport as well. In this regard, shame as an ethical category representing one of the supporting pillars of theological moral is almost disappearing from sports practice and sport competitions. We are witnessing common deception in sport (the use of performance-enhancing drugs, match-fixing, referee bias) which is degrading the traditional Olympic spirit and purity of sports performance and sporting events. Though there have been attempts to prevent those negative tendencies through generalisation and promotion of the fair play code of conduct (in order to level various codes of various societies and groups), its practical use is still far from what is expected.

A return to already approved values of Christian morality avoiding anything that is dishonourable, shameless and impermanent is highlighted in the paper.

Key words: ethics, Christianity, shame, deception in sport

Corresponding author

Jovo Radoš

lazarrados@gmail.com

\section{INTRODUCTION}

It is easy to notice a worldwide decreasing and losing of moral values and moral norms in any field of human existence. In this regard, one should remember that moral action encompasses any kind of human relationships: family life, political actions, cultural creativity, business activities, sports activities, etc. Hence, man's conscience (a rule inscribed in human heart by God) is always encountering challenges; whether our actions will take the path of virtue or the path of sin. Today's disordering of a traditional value system obviously tends to 
the latter. That is how axiological (globalised) requirement to achieve success anywhere and at any cost has led to many immoral activities and actions. In other words, people have started "to want more from the world than from the Lord" (St. Nikolai the Bishop).

Those outlined tendencies have neither missed sport. Giving an advantage to the result over ethics has generated an increased "Machiavellianism" within sports competitons. When increasingly dominant factors of politics and show business are added to the equation, it becomes obvious that very little of the former Olympic spirit and honesty have remained at sports competitions. Sport spirit has always been an ontological (essential) value of sports. It has always been characterised by fair play and respect for oneself and the opponents. Only that what is built on Truth, Good, Justice, Love and Wisdom can expect to be accepted as a value to aspire to. In other words, promotion of the Olympic spirit includes, first of all, encouragement to and exercise of moral traits arising from a true faith in God.

Any attempt to prevent or disguise deception in sport by a general implementaion of fair play code of conduct has remained almost unnoticeable in practice thus indicating all the weakness and inefficacy of such a designed intervention. Its common practical use in certain circumstances (congratulating an opponent on the winners podium, leaving the first track for the leading athletes in long-distance running, cooperation of runners in marathon, demanding a change of the referee decision against one's own good and in the aggrieved opponent's favour, and some other) has been usually reduced to kicking the ball out in order to assist an injured soccer player laying on the ground.

Our existential compliance with somewhat forgotten principles of theological ethics (and a category of shame in particular) is very important for establishing a common body and communion with God in the entire human life and thus in sports conduct as well. Otherwise, the less of God there is in man, the less of man there is in man (Father Justin Popović).

The truth is, however, there are moral codes of various societies and groups with certain disagreement among them. Thus, nowadays (and in the West in particular), ethical relativism prevails, which Allan Bloom in his bestselling book The Closing of the American Mind blames for many of the causes of moral and educational degradation in a number of structures of American society.

Indeed, moral relativism not only reflects ethical subjectivism but also stems from cultural diversities (for instance, with regard to sport, some societies pay much attention to the victory itself whereas some other societies also nurture the aesthetics of play).

Hence, although there are many today's people who discard "absolute" values (or doubt them), it should be noticed that moral judgements: what is right or wrong, what is fair or unfair, what is just or unjust exactly assume absolute values. 
After all, insisting on relativism as a sole criterium for establishing moral attitudes or moral judgements in general can easily turn into "anarchism, and anarchism to nihilism" (Father Justin Popović).

\section{ON SHAME}

With regard to one's own pride and prejudice and in compliance with a tendency to be truly grown in the faith of Christ, an important characteristic of our existence already indicated in the title deserves consideration. This is shame, which "has gone numb in many people" today, as Patriarch Pavle of blessed memory used to say. It is easy to recognise the incoming domination of brazen times. Only seldom someone can be seen blushing with shame. A well-known phrase "Shame on you!" which used to express a sharp reprimand seem to have completely disappeared. And it was not so long ago, said Father Mitrofan (the Chilandar Monastery), when our people were faithfull. Marriages were stable and children well raised. There used to be some traditional faith all around.

As early as in ancient times, Plato said that of all things measure was God and that there were two compelling forces to make use of norms and laws and that based on "reverence and fear" (Letters 337a).

In our oral tradition, there is a riddle in which a son asks his father what to be cautious about most in the world he is about to enter and his father answers: "About the fear of God and shame of man". In this regard, Vuk gives the following example in his Dictionary: no one wants to take the last piece left on the table because "everyone is ashamed". Long ago, recognised folk experience generated a saying: "Where there is fear, there is shame". This indeed refers to "God-given fear", from which the message that "anyone who believes in Him will never be put to shame" (Romans, 10:11) follows. In other words, nothing should be done which is not in accordance with theological ethics and virtue-loving practice. Therefore, a decasyllabic verse: "For, Marko is not afraid of anyone but God Almighty" can be found in our epic poetry.

However, modern psychology has a completely different approach to this issue. It attempts to find "rational" explanations of and solutions to how to overcome fear as something preventing man's emancipation. It is all about an intention to get "free from inherited dogmas" and "conservative" views. This focusing on assumed freedom (with no God) shapes man's conscience on a regular and general basis, which results in increasing socially deviant behaviour (such as drug addiction, sect boom, sexual perversion, money worship, horoscope and fortune-teller praise, etc.).

A return to already approved and everlasting values of our Sait Sava's ethos is therefore an inevitable ethical and educational tool, which can enable establishing of personal and collective balance and harmony and preserve a healthy essence of 
a nation and a society. Consequently, one should follow the example of "our holy forefathers who were able to maintain their faith and honour" (Patriarch Pavle).

Therefore, what is called the greatest of virtues and obligations of man results from the feeling of fear of God: "The fear of the Lord is wisdom and to turn away from evil is understanding" (Job, 28:28). In this regard, St. John Chrysostom says: "If there were no fear of the Lord, no sublime and good things can be done".

God, of course, acts not only on the "more fearful" but also on the "more benevolent" and "the obedient" (St. Nicholas, Srbadija, Žiča Ordinance, page 46). In his view, fear of God has different levels of meaning. On its lowest level, it is experienced as fear (anxiety) of God's punishment ("God, frighten but do not kill"); next, it is perceived as a surprise (awe, horror felt when faced with a colossal event) and a pious congenial life; and finally, the highest level of fear of God is experienced as a complete purity and sanctity of life.

Throughout its history, our people (as already pointed out) used to stick to their word and honesty ("no fear, no honesty") but the new time has ignored and suppressed this axiologial paradigm (with young people in particular), which is expressed in the saying: "Lost his face but not afraid of ......".

The lack of shame has particularly affected the area of sports competitions and sports performances. Professionalisation of sport and its adherence to the sports market and profit have produced the worldwide spread of shameless and immoral participation of athletes in various forms of unfair actions and deceptions. We will focus on some of them.

\section{EMPIRICISM OF DECEPTION IN SPORT}

The entire array exists of the observed and identified forms of deception, irregularities and injustice in sport, which have been revealed and confirmed in sports practice (whereas some of them are yet to be found and disclosed). They include, but are not limited to, the use of performance-enhancing drugs, partial referees decision making, and corruption and match-fixing in collusion with bookmakers as well as deception for commercial or political purposes. All of this is usually done without any shame or regret although some examples of athletes experiencing a belated feeling of guilt and a need to talk about it in public do exist.

The use of performance-enhancing drugs is a very common form of breaching both legal and moral norms and rules in a number of sports. It provides an unfair advantage (better results) to those using steroids. Although anti-doping testing is now carried out regularly, there are always those who try to fool the test and pass medical examination. It is thus a disguised form of cheating in sports and a competition has lost its essential function of testing actual sport skills. Competitors who obey rules of sport and sports ethics actually fight against 
"cyborgs" and "frankensteins" (artifical athletes) who, in addition to traditional steroids, increasingly use performance-enhancing drugs generated from genetic modifications. Although the IOC provides huge financial support to new advanced methods of detecting performance-enhancing drugs, it all looks like a cat-andmouse game because a new stronger generation of drugs appears soon after the previous one has been detected, in comparison to which the previous one seems almost harmless (Italian cyclist Riccardo Ricco tested positive for the third generation of notorious performance-enhancing drug of erythropoietin - EPO in 2008). Athletes are sometimes caught doping on time (several cyclists are disqualified for failing anti-doping test from the world's most prestigeous bicycle race Tour de France every year) but in most cases, confessions come later, only years after. One of the examples is Marion Jones, a track-and-field athlete who won five gold medals at the 2000 Olympic Games in Sydney and seven years later, she admitted at court that she had taken banned substances. The International Association of Athletics Federations erased all her results and took away all the medals she had won then and later. British track sprinter Dwain Chambers is (finally) honest and sincere in his autobiography when he admits taking more than 300 different banned performance-enhancing drugs. Also, Swiss tennis player Martina Hingis, one of the best tennis players of all times, admitted having taken cocaine. Diana Taurasi, the all-time leading basketball scorer (four-time European champion, two-time Olympic medalist, and one-time world's silver and bronze medalist) has recently tested positive for the banned substance.

The World Anti-Doping Agency (WADA) has sanctioned Russia (Russia's flag and anthem will not appear) for the Tokyo Games and the 2022 soccer World Cup in Qatar. The reason is Russian anti-doping agency's tempering with a Moscow laboratory database (many find political implications of the sanctions).

Moreover, Serbian athletes have not been spared the so-called "doping affairs" (several of our top athletes including some wrestlers, shot-putters, handball players and soccer players have recently tested positive for banned substances).

Match-fixing at sports competitions (particularly in sports where the results are used for sports betting) is one of the increasingly common phenomena which is destroying a true sporting spirit and sports ethics. For instance, match-fixing has been discovered many times at European football competitions. In 2007, UEFA contacted Interpol for a reasonable doubt in match-fixing at 15 matches in Eastern Europe. Similar doubts have been raised in other geographical regions. Match-fixing has also been reported in tennis. NBA referee Tim Donaghy was accused of betting on games he officiated.

Match-fixing also includes some "more innocent" practice of tailoring the outcomes, such as losing a match intentionally in certain team sports in order to compete against a weaker opponent in the next stage of the competition. Of 
course, it can be assumed that there are many other forms of match-fixing going on in sports practice.

Bias decision making and a referee's influence on the outcomes have been present at sports competitions for ages, which seriously obscures what sport is supposed to nurture as purity, beauty and the recognised ethical spirit of Olympism. Sports empiricism is full of demonstrations of referee biases and fixing of outcomes and surprising decisions made by sporting officials, which either favour hosts or individual athletes or teams for some financial or political reasons. Here are just some of them: Italian referee Collina awarded a penalty to the host in the 89th minute when the score was 0:0 although there was no foul play (UEFA also wanted the Netherlands as a host to proceed to the next stage of the competition). A judging scandal at 2002 Winter Games in Salt Lake City is also well-known, where after five days of investigation and speculation the decision was made to declare a tie and the Canadian pair shared "gold" with the Russian pair in pairs figure skating after 5 of the 9 judges had awarded fist-place ordinals to the Russians. We all remember a victory stolen from our swimmer Milorad Čavić at the 2008 Beijing Games (in a 100-meter butterfly final) where American champion Michael Phelps was declared a winner only a hudredth of a second "ahead" of Čavić although it was obvious that Čavić had touched the pad first. Specifically, Swiss company Omega (one of the largest corporate sponsors of Phelps) refused to release the underwater video images of the final. The reason stated was a decision made by International Swimming Federation FINA not to release the footage.

A number of theoretical and empirical scientific investigations study whether referee is bias or not. Thus, among other things, there is a scientific study on the nature, character and scope of referee bias in rhythmic gymnastics - Sydney 2000 Olympic Gymnastics Rhythmic (R. Popović, 2004). Namely, starting from the assumption that the effects of partial (biased) referee decision making are the most dramatic in sports where officials can judge the performance of athletes by combining objective and subjective criteria (sports and rhythmic gymnastics, figure skating, diving, karate katas, etc.), it can be concluded (by applying exact indicators) that in the abovementioned competition, bias was demonstrated in two ways: 1 . in favour of gymnasts of the same nationality as particular officials and 2. against their immediate opponents (rivals) of different nationalites. Briefly, the findings of the study have indicated the presence and demonstration of referee bias among international officials.

\section{CONCLUSION}

There are indeed stated legislative principles and prescribed rules in sport intended to regulate reletionships in this huge social area. These principles and 
rules should be followed by all the participants in a particular competition or a match (competitors, officials, coaches, chief officers, spectators). However, as in any other area of social life, there are distinct and specific codes of conduct regarding solely the ethical dimensions of sport. They are used to promote dignity, personal respect, equity and justice among athletes.

However, since deviations from the original principles are too frequently observed in modern sports practice and developing trends morals have been ignored and suppressed to the background. Fair play code is most frequently referred to in searching for remedies. Full responsibility for its implementation is expected to be taken by governments, sports organisations (federations, executive boards, institutions, medical and pharmaceutical chambers, media) but also at an individual level by athletes, parents, teachers, coaches, officials, delegates, sports managers, journalists and others. It should be noted that those principles are declaratively approved in international sport.

Nevertheless, with regard to the described subject, it can be concluded that all those remedies are somewhat poor if not supported by true faith and education thereto. Consequently, sport can serve anyone for spiritual benefits if it is marbled with appreciation for elementary Christian values. For example, if an athlete becomes famous, he or she should not turned overwhelmed by pride, conceit and narcissism. Moreover, affluence earned from professional playing of sport should not be a reason for living a hedonistic lifestyle, overspending, exaggerating in luxury and overbearing manners. Thus, one should always remember the words of Saint Paul the Apostle in his Epistles where, describing life struggles, deeds, credits and awards, he uttered the following thoughts (among others):

- Everyone who competes in games, races and arenas does it to receive a "perishable wreath and every man that striveth to be sound in faith "an imperishable crown" that is, "a crown of righteousness", which the Lord, the righteous judge, shall give.

Therefore, one should not greed for anything dishonourable, shameless and impermanent but attempt to live as "pure" life as possible for the glory of God and in communion with Him.

\section{REFERENCES}

1. Bloom, Allan, The Closing of the American Mind, Simon and Schuster, New York, 1987

2. Patriarch Pavle, Iz dana u dan [From Day to Day], Belgrade, 2018

3. Plato, The Letters, Krovovi, Sremski Karlovci, 1998

4. Popović,Father Justin, Filosofske urvine [Cliffs of Philosophy],Belgrade, 1987

5. Radoš, Jovo, Etika u sportu [Ethics in Sport], Kairos, Sremski Karlovci, 2011 
6. Radoš,Jovo, Filozofija religije [Philosophy of Religion], DNS Logos, Bačka Palanka, 2012

7. Radoš, Jovo, Filozofija sporta [Philosophy of Sport], Kairos, Sremski Karlovci, 2016

8. Radoš, Jovo, Srpska narodna filozofija [Philosophy of the People of Serbia], Zavod za kulturu Vojvodine, Kairos, Novi Sad, Sremski Karlovci, 2017

9. Saint Paul the Apostle, Poslanice [Epistles], Novi zavjet, Biblijsko društvo Srbije, 2018

10. Velimirovich, St. Nikolai, Molitva na jezeru, [Prayers by the Lake], EVRO BOOK, Belgrade, 2018

11. Velimirovich, St. Nikolai, Srbadija, Žički ustav [Srbadija, Žiča Ordinance], Vojlovica, 2011

\title{
ОДСУСТВО СТИДА И СПОРТСКЕ ОБМАНЕ
}

\section{САЖЕТАК}

Тематску окосницу у овом раду чини осврт на свеукупну појаву слабљења и лабављења моралних вредности и моралних норми у свим сферама људског бивствовања, па тиме и у спорту. Самим тим, етичка категорија стида, која представља један од носећих стубова богословског морала, готово да сасвим ишчезава и у окриљу спортских делатности и спортских такмичења. Сведоци смо учесталих спортских превара (допинговање, лажирање, необјективно суђење), које деградирају традиционални олимпијски дух и чистоту спортских наступа и спортских догађања. Додуше, постоје покушаји да се те негативности спрече, кроз универзализацију и афирмацију кодекса фер-плеја (како би се нивелисали различитих кодова различитих култура и група), али његова практична примена је далеко од жељених очекивања.

Зато се у раду потенцира враћање провереним вредностима хришћанског морала, у коме се указије да треба избегавати све што је нечасно, бестидно и пролазно.

Кључне речи: етика, хришћанство, стид, спортске преваре

\section{СПОРТ БЕЗ СТЫДА И ОБМАНА}

\begin{abstract}
АННОТАЦИЯ
Статья посвящена краткому обзору в мировом масштабе снижения и утраты моральных ценностей и моральных норм в любой области человеческого существования, а также в спорте. В связи с этим стыд как этическая категория, представляющая собой один из опорных столпов теологической морали, практически исчезает из спортивной практики и
\end{abstract}


спортивных соревнований. Мы являемся свидетелями распространенного обмана в спорте (использование препаратов, повышающих производительность, договорные матчи, предвзятость судей), который унижает традиционный олимпийский дух, чистоту спортивных результатов и спортивных мероприятий. Хотя предпринимались попытки предотвратить эти негативные тенденции путем обобщения и продвижения кодекса поведения в честной игре (с целью выявления уровня кодексов различных обществ и групп), его практическое использование все еще далеко от ожидаемого.

В статье подчеркивается возврат к уже утвержденным ценностям христианской морали, избегающим всего бесчестного, бесстыдного и непостоянного.

Ключевые слова: этика, христианство, стыд, обман в спорте.

Reccived on 09.03.2021.

Accepted on 19.04.2021. 